\title{
Inclusion through football: The case of Diverse City FC
}

\author{
James Carr \\ Department of Sociology, University of Limerick, Limerick, Ireland. \\ Martin J. Power \\ Department of Sociology, University of Limerick, Limerick, Ireland.
}

(C) James Carr and Martin J. Power. This work is licensed under the Creative Commons AttributionNonCommercial-NoDerivatives 4.0 International License. To view a copy of this license, visit http://creativecommons.org/licenses/by-nc-nd/4.0/.

\begin{abstract}
In this piece we document how a football club has proved to be an important mechanism of integration for young Muslim women in Ireland. As has been evidenced elsewhere, ${ }^{1}$ and discussed in this piece, Islamophobia is a reality in Irish society, whether as proximal lived experiences of hostility and discrimination, or as structural elements that deploy anti-Muslim tropes. In the face of such exclusion, young Muslim individuals, supported by local civil society actors, have taken it upon themselves to develop a platform, namely the Hijabs and Hat-tricks project, that not only enables inclusion, and develops meaningful integration, but also challenges head-on those tropes that cast them and their communities as 'other'. Football, in the form of Diverse City FC, forms the focal point of this platform. Based on the experiences of these young Irish Muslims, we argue that football, and indeed sport more broadly, can act as an incredibly effective mechanism for meaningful societal integration. Finally, we argue for the importance of not only understanding the experiences of marginalised groups, such as the Diverse City players, but of the importance of drawing from these experiences to design future strategies for inclusion in Irish society.
\end{abstract}

Keywords: Islamophobia; Anti-Muslim racism; Ireland; Social Inclusion; Integration

\section{Islamophobia in Irish society and the racialisation of Muslim women}

Ireland has become increasingly diverse over the last 30 years. Many migrants who have made Ireland their home have lived here for a considerable amount of time and had families grow up

\footnotetext{
${ }^{1}$ James Carr, Experiences of Islamophobia: Living with racism in the neoliberal era (London: Routledge, 2016).
} 
here. Cultural diversity is now a permanent reality for Irish society. ${ }^{2}$ Group conflict theory ${ }^{3}$ maintains that how members of 'outgroups' are depicted and understood is conditional on whether they present a prospective hazard to the advantages enjoyed by the 'ingroup'. 4 Leadership on the matter is thus of crucial importance for framing the issues of immigration and integration, as it can have a significant impact on how the general public views immigrants and cultural minorities in our society. Haynes et al. ${ }^{5}$ warned that failures by political parties to address immigration and integration 'as important policy areas and the reticence of some party representatives to communicate on these issues to the public creates a vacuum, which may be filled by those who adopt an anti-immigrant stance'. A decade later we now see that both mainstream and marginal political actors in Ireland have embraced and espoused discourses replete with anti-immigrant and anti-Muslim/Islam tropes. Carr ${ }^{6}$ documents that thirty candidates ran on anti-immigration platforms in the 2020 general election, and some had very clear positions on Muslims and Islam in Ireland. ${ }^{7}$ In general, these parties and candidates performed abysmally in the election, although an independent candidate who had previously claimed that asylum seekers in Ireland have been 'infiltrated by ISIS' was elected. ${ }^{8}$

While the mainstream media have provided overwhelmingly positive coverage of events such as the Eid-al-Adha celebration held in Croke Park in 2020, anti-Muslim discourses are also present in Irish media, both mainstream and social. Media coverage of Muslim communities in Ireland, as documented in a number of Islamophobia Reports, has evidenced the problematic use of language, for example, co-locating Muslim/Islam(ic) with terms such as terrorism and extremism, which serve to potentially stigmatise Muslim communities. ${ }^{9}$ Writing in relation to Irish people who convert to Islam, Carr argues that the presence of a 'cause and effect' frame in media reports presents converts to Islam as being on an inevitable path to 'extremism'. ${ }^{10}$ Additionally, documentaries, such as Ireland's Jihadis, which originally aired in 2018, aid a narrative that Ireland is a soft target for terrorism and a base for 'Islamic

\footnotetext{
${ }^{2}$ Department of Justice \& Equality: Office for the Promotion of Migrant Integration, The Migrant Integration Strategy: A Blueprint for the Future, 6, accessed August 10, 2020, http://www.justice.ie/en/JELR/Migrant_Integration_Strategy_English.pdf/Files/Migrant_Integration_Strategy_E nglish.pdf.

${ }^{3}$ Herbert Blumer, "Race Prejudice as a Sense of Group Position," The Pacific Sociological Review 1, no. 1 (Spring 1958).

${ }^{4}$ Martin Power, Amanda Haynes, and Eoin Devereux, "From the mouths of Janus: Political Constructions of Transnational EU Migrants," Irish Communications Review 13, no. 1 (2012): 4.

${ }^{5}$ Amanda Haynes, Martin Power, and Eoin Devereux, How Irish Politicians Construct Transnational EU Migrants (Limerick: Doras Luimní, 2010), iii.

6 James Carr, "Ireland 2020," in the European Islamophobia Report 2020, edited by Enes Bayrakli and Farid Hafez, accessed December 7, 2020, https://www.islamophobiaeurope.com/.

${ }^{7}$ Conor Gallagher, "Election 2020: Far-right candidates put in dismal showing," The Irish Times, February 10, 2020.

${ }^{8}$ Jennifer Bray, "Verona Murphy apologises “wholeheartedly' for Isis migrants claim," The Irish Times, November 18, 2019.

9 James Carr, "Ireland 2019," in the European Islamophobia Report 2019, edited by Enes Bayrakli and Farid Hafez, accessed December 7, 2020, https://www.islamophobiaeurope.com/; James Carr, "Ireland 2018," in the European Islamophobia Report 2018, edited by Enes Bayrakli and Farid Hafez, accessed December 7, 2020, https://www.islamophobiaeurope.com/; James Carr, "Ireland 2017," in the European Islamophobia Report 2017, edited by Enes Bayrakli and Farid Hafez, accessed December 7, 2020, https://www.islamophobiaeurope.com/; James Carr, "Ireland 2016," in the European Islamophobia Report 2016, edited by Enes Bayrakli and Farid Hafez, accessed December 7, 2020, https://www.islamophobiaeurope.com/; James Carr, "Ireland 2015," in the European Islamophobia Report 2015, edited by Enes Bayrakli and Farid Hafez, accessed December 7, 2020, https://www.islamophobiaeurope.com/.

${ }^{10}$ Carr, "Ireland 2020."
} 
extremists'. Claims such as these continue to construct Muslim men and women as a 'suspect community' in Ireland. ${ }^{11}$

Islamophobia operates across a range of spheres in contemporary Irish society. Previous research has documented the ways in which institutional practices have, for example, limited the ability of Muslim children to access their schools of choice (Carr 2016c). ${ }^{12}$ In July 2020, the Ombudsman for Children published a report that documented the experiences of Muslim children in Direct Provision centres attending school. ${ }^{13}$ The Ombudsman report highlights that 'some girls were afraid to wear traditional dress such as the hijab ${ }^{14}$ as this exposed them as Muslim and therefore a target for hostility'. While Carr ${ }^{15}$ notes that there are examples of ' $g o o d$ practice on the part of schools, including the provision of prayer rooms by principals', other schools have banned the wearing of the hijab on the basis of 'health and safety or a uniform code', which has resulted in 'some girls having to remove their head scarves at the school gates or opting for other schools that allowed it'. ${ }^{16}$ This is a crucial point. A key focus of the racialising discourses which have been assigned to Muslim women is their hijab, which has become a target for structural/institutional/governmental and interpersonal efforts to manage the freedom of Muslim women in the 'West.' Increasingly, Muslim women are targeted in political discourses and practices that focus on their Islamic identities and restrict their freedom to choose how they manifest their faith in public settings. ${ }^{17}$ In an interview on the topic of increasing racism in Ireland with an Irish tabloid newspaper in March 2020, for example, Irish Muslim, Lorraine O'Connor from the Muslim Sisters of Éire, recalled that despite her white Irishness, she was racialised and othered on the basis of her religious dress. ${ }^{18}$

In 2019, the Irish Network Against Racism (INAR) released data on the levels and experiences of racism in Ireland, including towards Muslims, which documents physical assault, threats, harassment, verbal abuse and discrimination. ${ }^{19}$ Additionally, data from iReport provided to Carr by INAR also clearly evidences hostility and discrimination towards Muslims in Ireland. ${ }^{20}$ Carr has previously demonstrated that Muslim women experience hostility and

\footnotetext{
${ }^{11}$ Ibid; Paddy Hillyard, Suspect community: people's experience of the Prevention of Terrorism Acts in Britain (London: Pluto Press, 1993).

12 James Carr, Islamophobia in Dublin: Experiences and how to respond. Dublin: Immigrant Council of Ireland, 2016.

${ }^{13}$ Ombudsman for Children, Direct Division: Children's views and experiences of living in Direct Provision: A report by the Ombudsman for Children's Office 2020, accessed November 10, 2020,

https://www.oco.ie/app/themes/oco/images/direct-division/pdf/Ombudsman-for-Children-Direct-DivisionReport-2020.pdf.

${ }^{14} \mathrm{~A}$ head scarf, of religious significance to the wearer, that is readily identified as being associated with Islam and has come to symbolise the racialised understanding of the (alleged) oppressed position of women in Islamic societies and communities (Chris Allen, Islamophobia (London: Routledge, 2010) and Homa Hoodfar, "The Veil in Their Minds and on Our Heads: The persistence of colonial images of Muslim women," Resources for Feminist Research 22, no. $3 / 4$ (1993): 5-18.)

${ }^{15}$ Carr, "Ireland 2020."

${ }^{16}$ Ombudsman for Children, Direct Division: Children's views and experiences of living in Direct Provision: A report by the Ombudsman for Children's Office 2020.

${ }^{17}$ Carr, Experiences of Islamophobia: Living with racism in the neoliberal era; Deepa Kumar, Islamophobia and the Politics of Empire (Chicago: Haymarket Books, 2012); Shakir Hussein, Scheherazade Bloul, and Scott Poynting, "Diasporas and dystopias on the beach: Burkini wars in France and Australia," in The Routledge International Handbook of Islamophobia, edited by Irene Zempi and Imran Awan (London and New York: Routledge, 2019), 263-75.

18 Aoife Finneran, "Rise of Racism. Irish Muslim tells how racists told her to 'go back to where you came from' - despite being born in Dublin's Coolock," The Irish Sun, March 20, 2020.

${ }^{19}$ Lucy Michael, Data from iReport.ie: Reports of Racism in Ireland 2019, Irish Network Against Racism, https://inar.ie/wp-content/uploads/2020/03/2019_iReport_Final.pdf.

${ }^{20}$ Carr, "Ireland 2020."
} 
discrimination at greater rates than their male counterparts in Ireland. ${ }^{21}$ In a study with 323 participants, of those who indicated that they had experienced hostility, $44 \%$ of Muslim women reported that they had compared to $28 \%$ of Muslim men. While this primarily took the form of verbal abuse $(80 \%)$, a considerable number $(22 \%)$ of the participants also reported experiences of physical assault. Moreover, $40 \%$ of Muslim women reported experiencing explicitly antiMuslim discrimination across a range of sectors, such as in work or when looking for work, accessing education and using public transport, while the corresponding figure for Muslim men was $22 \%$. While recognising the myriad diversity vis-à-vis identities ${ }^{22}$ of Muslim women in Ireland, $\mathrm{Carr}^{23}$ argues that processes of racialisation, which construct 'Others' as other, thus legitimising related exclusionary practices (see also Carr and Haynes ${ }^{24}$ ), are at the heart of all racisms.

\section{The Policy Context of Sport and Integration / Inclusion}

Irish policy defines integration as the 'ability to participate to the extent that a person needs and wishes in all of the major components of society without having to relinquish his or her own cultural identity'. ${ }^{25}$ In November 2004, all of the European Union (EU) Member States agreed upon the EU Common Basic Principles with the aim being 'to assist Member States in formulating integration policies by offering them a ... guide of basic principles against which they can judge and assess their own efforts'. ${ }^{26}$ The EU Member States agreed that integration occurs concurrently at the level of the individual, family, community and the State, in all aspects of life, and can extend over more than one generation. Repeated contact between migrant communities and the 'native' population and intercultural conversations about migrant communities and their cultures are amongst a number of interventions that serve to enhance the integration process. ${ }^{27}$

These principles in turn influenced the Migrant Integration Strategy, published in February 2017, which sets out the approach the Irish Government is taking to the integration of migrant communities. While the document recognises that integration is a two-way process that encompasses involvement by migrant communities and wider Irish society, apart from an image of a Muslim woman wearing a hijab on the front page, the only specific reference to Muslim communities states that 'Radicalisation has been a particular issue for other European societies where ideologies that seek to undermine the state have prompted some young people, particularly second-generation Muslim immigrants, to undertake terrorist actions' ${ }^{28}$ Representations such as this replay Islamophobic constructions of Muslims, young and old, migrants or otherwise, and those who have converted to Islam as being somehow vulnerable or prone to engaging in violence purely on the basis of their religious beliefs, communicating

\footnotetext{
${ }^{21}$ Carr, Experiences of Islamophobia: Living with racism in the neoliberal era.

${ }^{22}$ Aarti Ratna, "'Taking the power back!' The politics of British-Asian female football players,” Young 18, no. 2 (2010): 117-132.

${ }^{23}$ Carr, Experiences of Islamophobia: Living with racism in the neoliberal era.

${ }^{24}$ James Carr and Amanda Haynes, “A Clash of Racialisations: The policing of 'race' and anti-Muslim racism in Ireland," Critical Sociology 41, no. 1 (2015): 21-40.

${ }^{25}$ Department of Justice, Equality and Law Reform, Integration: A Two Way Process (Dublin: Department of Justice, Equality and Law Reform, 1999).

${ }^{26}$ Council of Europe, PRESS RELEASE 2618th Council Meeting: Justice and Home Affairs, 16, accessed

August 10, 2020, https://ec.europa.eu/migrant-integration/?action=media.download\&uuid=29C7FD4E-BA62D4EA-18A8C8B34E873190.

${ }^{27}$ Council of Europe, PRESS RELEASE 2618th Council Meeting: Justice and Home Affairs, 15-18.

${ }^{28}$ Department of Justice \& Equality: Office for the Promotion of Migrant Integration, The Migrant Integration Strategy: A Blueprint for the Future.
} 
that Muslims are a 'suspect community' in Ireland. ${ }^{29}$ Further, while integration is acknowledged as a two-way process, presenting Muslims in this manner holds the counterproductive potential of actually discouraging the participation of Muslim communities and individuals in broader socio-political processes, while also running the risk of being used to legitimise the acts of those who would engage in anti-Muslim discourses and practices.

The strategy document contains 76 broad actions to be implemented to increase integration, including social inclusion, promoting intercultural awareness, tackling racism and the use of sport. ${ }^{30}$ The then Minister of State at the Department of Justice and Equality with special responsibility for Equality, Immigration and Integration argued in the document that

Communities play a crucial role in making those living within them feel at home. We have to mobilise communities to promote integration. We have to engage sporting organisations, faithbased groups, cultural organisations, community groups more actively in the integration process. ${ }^{31}$

In the context of this piece, Action 73 of the Migrant Integration Strategy states that the potential of sport in assisting migrant communities to integrate into Irish society will be 'further explored through encouraging active participation, volunteering and involvement in governance' in, and of, those sports. ${ }^{32}$ While 'sport may be perceived as a rather trivial and peripheral activity', the rationale for investment in sport as a tool to encourage social inclusion has been increasingly embraced in recent years internationally (see Spaaij et al. ${ }^{33}$ and Coalter ${ }^{34}$ ).

There are two essential aspects of sport and social inclusion - inclusion in sports and inclusion through sport - that aim to include people on 'multiple domains'. ${ }^{35}$ With that understanding, we note the mission of Sport Against Racism Ireland (SARI), which was established in 1997. SARI aims to 'promote and support cultural integration, social inclusion and cohesion ... by using sport as a medium to combat racism, sectarianism, xenophobia, homophobia and all other forms of discrimination'. SARI has harnessed the potential of sport to develop grassroots projects, build its volunteer capacity, create 'safe spaces free from discrimination and xenophobia always mindful that integration and engagement off the playing fields is equally important'. Through its work it has encouraged 'new' and 'local' 'communities to share commonalities and value difference'. ${ }^{36}$ Previous research has documented that those from a 'non-western ethnic background and women in general are more likely to experience exclusion, and less likely to be volunteering and participating in sports'. This has underpinned the promotion and implementation of both individual and community level sports-based intervention policies with these communities in order to bring about more inclusion (Collins \& Haudenhuyse 2015, 6). ${ }^{37}$

\footnotetext{
${ }^{29}$ Hillyard, Suspect community: people's experience of the Prevention of Terrorism Acts in Britain.

${ }^{30}$ Department of Justice, The Migrant Integration Strategy.

${ }^{31}$ Department of Justice \& Equality: Office for the Promotion of Migrant Integration, The Migrant Integration Strategy: A Blueprint for the Future.

${ }^{32}$ Ibid, 34.

${ }^{33}$ Ramón Spaaij, Jonathan Magee, and Ruth Jeanes, Sport and social exclusion in global society (New York: Routledge, 2014).

${ }^{34}$ Fred Coalter, "Sport-for-Change: Some Thoughts from a Sceptic," Social Inclusion 3, no. 3 (2015): 19-23.

${ }^{35}$ Mike Collins and Rein Haudenhuyse, "Social Exclusion and Austerity Policies in England: The Role of

Sports in a New Area of Social Polarisation and Inequality?" Social Inclusion 3, no. 3 (2015): 6.

${ }^{36}$ Sports Against Racism Ireland, "Positive Integration and Social Inclusion Through Sport," accessed

November 20, 2020. https://www.sari.ie/.

${ }^{37}$ Collins and Haudenhuyse, "Social Exclusion and Austerity Policies in England: The Role of Sports in a New Area of Social Polarisation and Inequality?" 6.
} 
Accordingly, sport is increasingly being seen as a way to extend the reach of integration and social inclusion programmes to places and communities that are considered 'harder to reach through more traditional political and civic activities' (see Parnell and Richardson ${ }^{38}$ ). Because of its global interest, strong local loyalties and facilitation of the 'public performance of communal identities', football is a hugely influential sport for billions of people (see Power et al. ${ }^{39}$ ), and when 'a game matters to billions of people it ceases to be just a game. Football is never just football' ${ }^{40}$ For the past two decades, the Football Association of Ireland (FAI), for example, have been engaged in a range of grassroots activities with football clubs and associates to challenge racism and 'encourage participation in football among people from minority ethnic and cultural backgrounds'. ${ }^{41}$ In 2017, the FAI successfully secured funding from the Asylum, Migration and Integration Fund of the European Commission to develop further initiatives to encourage integration in Irish society through football. ${ }^{42}$ The 'Integration Through Football' (ITF) project had a three-year timescale (2017 to 2020) and built on previous efforts by the FAI to encourage integration, support interculturalism, tackle racism and increase involvement in sport amongst the numerous ethnic communities resident in Ireland. ${ }^{43}$ The project aimed to bring 'community groups and grassroots football clubs together to build alliances ${ }^{44}$ and support programmes', which consisted of 'Futsal, Volunteering in Football, Football and Language, and After-school/Club open days'. ${ }^{45}$ An evaluation of the ITF project identified that in addition to the physical benefit of participation, the educational programmes were beneficial to participants, ${ }^{46}$ as were the ways in which the different aspects of the project brought the different communities together (see Ní Chonaill ${ }^{47}$ for a further discussion). Participants noted that the ITF project provided a platform for inclusion for people who otherwise may not have been enabled to participate in sport. For example, the parents of children involved became volunteers in football clubs and as a consequence were active in the community, enabling broader inclusion and integration.

\footnotetext{
${ }^{38}$ Daniel Parnell and David Richardson, "Introduction: Football and inclusivity," Soccer \& Society 15, no. 6 (2014): 823-27.

${ }^{39}$ Martin Power, James Carr, Daniel Parnell, Paul Widdop, and Stephen Millar, "Introduction: Understanding The Connection Between Football, Identity and (P)politics," in Football, Politics and Identities, edited by James Carr, Daniel Parnell, Paul Widdop, Martin Power, and Stephen Millar (London and New York: Routledge, 2021), 3 .

${ }^{40}$ Simon Kuper, Football Against the Enemy (London: Phoenix, 1996), 1.

${ }^{41}$ Football Association of Ireland, Take Part / Programmes, accessed January 19, 2019. .https://www.fai.ie/domestic/take-part-programmes/intercultural-programme. 2018

${ }^{42}$ Brid Ní Chonaill, Integration Through Football Project: First phase evaluation. What we know so far? Report for the Football Association of Ireland, accessed February 21, 2019. https://www.fai.ie/sites/default/files/atoms/files/Integration\%20Through\%20Football\%20Project\%20first\%20ph ase\%20Report.pdf.

${ }^{43}$ Ibid.

44 The creation of these alliances was premised on the ability to develop "effective community partnerships" as identified in the FAI's Intercultural Football Plan (Football Association of Ireland, Intercultural Football Plan Many Voices One Goal (Dublin: FAI, 2007), accessed January 19, 2019, https://www.fai.ie/sites/default/files/atoms/files/FAI_INTERCULTURAL_PLAN\%20v1.pdf.

${ }^{45}$ Brid Ní Chonaill, Integration Through Football Project: First phase evaluation. What we know so far? Report for the Football Association of Ireland, 11.

${ }^{46}$ For example, participants on the Football and Language programme developed increased English language competency which is seen as a prerequisite for integration to Irish Society (Ní Chonaill 2018, 22).

${ }^{47}$ Brid Ní Chonaill, Integration Through Football Project: First phase evaluation. What we know so far? Report for the Football Association of Ireland.
} 


\section{Methodological Approach}

The research documented in this article is part of a larger evaluative study of the Hijabs and Hat-tricks project (See Carr et al. ${ }^{48}$ ). All the participants were initially contacted by the project partner, SARI, in order to gage their interest in taking part in the study. Ethical approval for the project was granted by the University of Limerick. The specific findings discussed in this piece originate from two focus groups we held with seven young women aged under 18 and eight young women aged 18 and over who played for Diverse City. Most of these young women were Muslim, but given the inclusive ethos of the project, we also had three participants from a Christian background. A diverse range of ethnic and national heritages were represented, including African, Arabic, Eastern European, Irish and South Asian. To protect the identities of participants, pseudonyms are used throughout this piece.

As we have argued previously, ${ }^{49}$ being 'outsiders' gave us an opportunity to operate with a beneficial naivety, which in turn gave us a platform to probe into issues a little deeper than someone from an 'insider' position may have chosen to do. ${ }^{50}$ Grounded theory provided us with a mechanism for developing categories (open coding), interlocking these categories (axial coding), building a story to join those categories together (selective coding) and ending with a set of discursive theoretical proposals (see Flick ${ }^{51}$ for a discussion of how this process works). In order to develop a set of discursive theoretical proposals on how the players of Diverse City negotiate their participation in football, both as individuals and as a group, we utilised a theoretical framework consisting of elements of Bourdieu' ${ }^{52}$ insights on Capital and Kemper and Collins ${ }^{53}$ work on micro level interactions. This framework enabled us to understand what was happening in the 'micro-level battle[s]' between our participants and the various power holders they were engaging with. ${ }^{54}$

\footnotetext{
48 James Carr, Amanda Haynes, Martin Power, Jennifer Schweppe, and John Garland, More than a club; More than a game: Contribution to the evaluation of the Hijabs and Hat-tricks Project, Unpublished Research Report, accessed August 10, 2019,

https://www.researchgate.net/publication/274195035_More than_a_club_more than_a_game_Contribution_to the evaluation of the Hijabs_and_Hat-tricks_project.

${ }^{49}$ James Carr and Martin Power, "More than a Club, More than a Game: The Case of Diverse City," Managing Sport and Leisure 25, nos.1-2 (2020): 99-113.

${ }^{50}$ Kristin Walseth, "Young Muslim women and Sport: The impact of identity work," Leisure Studies 25, no. 1 (2006): 75-94.

${ }^{51}$ Uwe Flick, An Introduction to Qualitative Research, $3^{\text {rd }}$ Ed. (London: Sage, 2006), 296-303.

${ }^{52}$ Pierre Bourdieu, "The Forms of Capital," in the Handbook of Theory and Research for the Sociology of Education, edited by John G. Richardson (New York: Greenwood Press, 1986), 241-58.

${ }^{53}$ Theodore D. Kemper and Randall Collins, "Dimensions of Microinteraction," The American Journal of Sociology 96, no. 1 (1990): 32-68.

${ }^{54}$ Martin Power, "Outwitting the Gatekeepers of the Purse: The Impact of Micro Level Interactions in Determining Access to the Back to Education Allowance Welfare to Education Programme," International Review of Modern Sociology 35, no. 1 (2009): 29.
} 


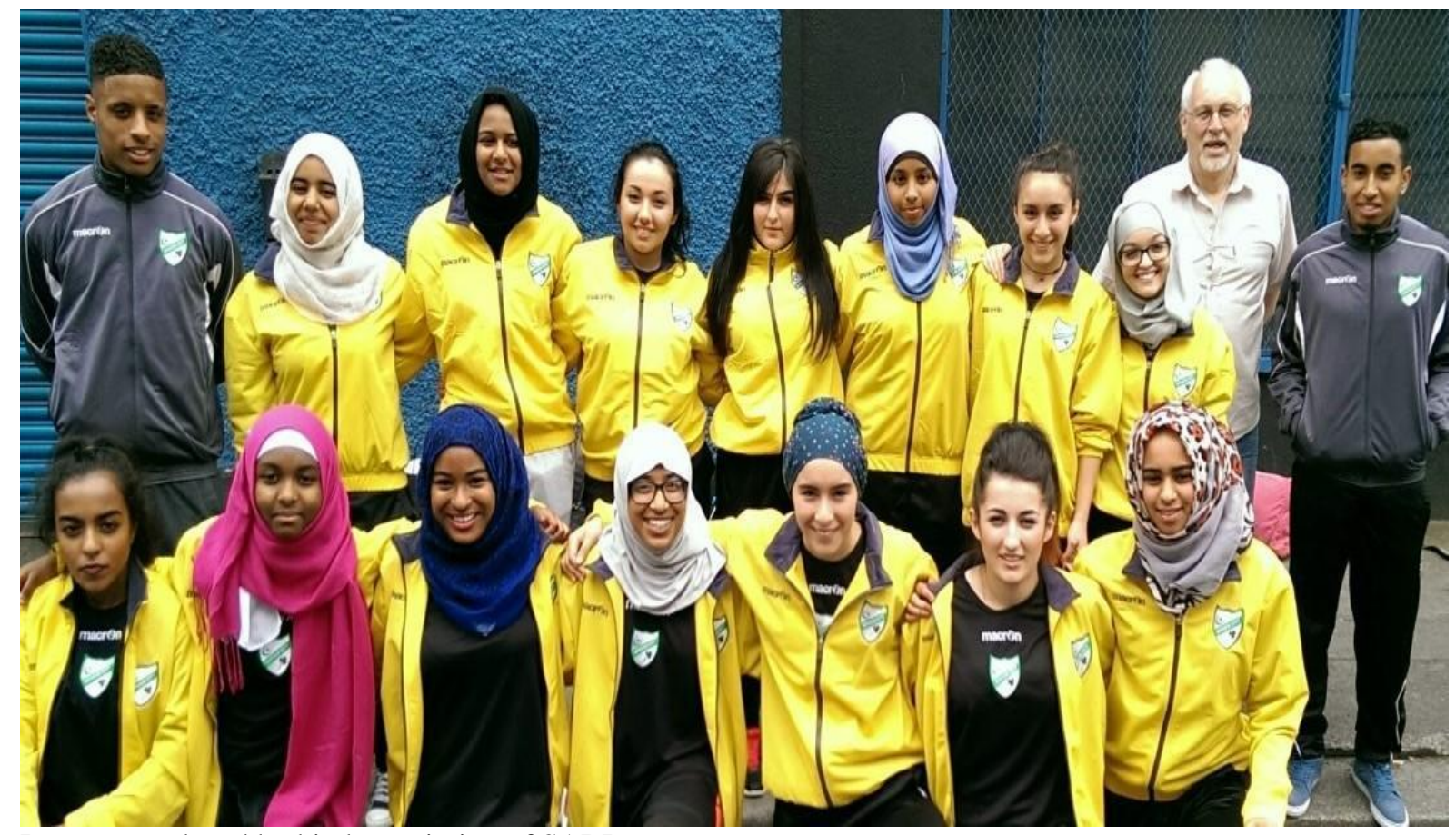

Image reproduced by kind permission of SARI.

\section{A Special Team: Introducing Diverse City FC}

'[Diverse City's] main purpose is starting up a Muslim team and raising awareness by wearing the headscarf and I think they did a good thing by allowing other people of different backgrounds and religion to show that we are all equal we are one it doesn't matter where you are from and all that...' (Deepa)

In 2007 FIFA introduced a ban on wearing a hijab in sporting competition. As a FIFA member state that ban was rigorously enforced by the $\mathrm{FAI}^{55}$, and those girls who wore the head covering were prevented from playing with established clubs or participating in activities such as the Soccer Sisters Summer projects and coaching courses.

The ban was overturned in 2014 by the International Football Association Board (IFAB), 'the institution that oversees the rules of the game and is the ultimate rule-making body of the sport ... The IFAB agreed that after a trial period "there was no indication as to why the wearing of head covers should be prohibited"". ${ }^{56}$ The change in ruling saw two young Muslim youth leaders, who were involved with and supported by Ken McCue of Sports Against Racism Ireland, Abdulkadir Abdallah and Abdul-Rahman Hajji, set up the Hijabs and Hat-tricks project in Dublin. The programme has twenty-five participants. The main aim of the programme is to encourage and support the participation of Muslim women in football in Dublin, and it was sponsored by Sony and Street Football World, who donated money to buy tracksuits, training gear and football kits (see SARI ${ }^{57}$ ).

\footnotetext{
${ }^{55}$ Organisations such as the Gaelic Athletic Association (GAA) had no such issue with head coverings and many of those involved with the Hijabs and Hat-tricks project played Camogie and Gaelic Football for their schools and GAA clubs.

${ }^{56}$ Cesar R. Torres and Douglas W. McLaughlin, "FIFA and the Lifting of the Ban on the Hijab," Play The Game, accessed November 11, 2020. https://www.playthegame.org/news/news-articles/2014/fifa-and-thelifting-of-the-ban-on-the-hijab/.

${ }^{57}$ Sports Against Racism Ireland, "Hijabs and Hat-tricks," accessed November 11, 2020, http://www.sari.ie/hijabs-and-hat-tricks/.
} 
The centre piece of the Hijabs and Hat-tricks programme is Diverse City Football Club, which was established in 2014 to provide a space where young Muslim women could play football. ${ }^{58}$ From the outset it was (and remains) open to players from diverse backgrounds. ${ }^{59}$ Initially, fifteen Muslim girls joined the club, and after only a few weeks of training, the team made their competitive debut on World Refugee Day at the Fair Play Cup, a competition organised by SARI and UNHCR. ${ }^{60}$ Those involved with Diverse City continue to train every week in the Garda Grounds in Dublin's Phoenix Park and play in exhibition games and SARI tournaments. Since its inception, the Hijabs and Hat-tricks' project, and the young people involved, have gone from strength to strength, winning both national and international awards, including the Best New Project Award at the prestigious Beyond Sport Awards in London in 2015. ${ }^{61}$ The Hijabs and Hoops project is in development and will be set up in 2021, along with a young Hijabis Academy, with the funding coming from the Coca-Cola Thank You Fund and FIFA's Football for Hope fund, through SARI's membership of streetfootballworld.

Previous research (see Bradbury ${ }^{62}$ ) has shown how, faced with exclusion and limited opportunities to play football, members of minority communities respond by forming their own teams. These teams ultimately become spaces for players to express their identities in a safe environment (see, for example, Scraton et al. ${ }^{63}$ and Ahmad $^{64}$ ) resulting in a feeling of belonging. ${ }^{65}$ In a similar fashion, it was clear from our participants that the players and coaches of Diverse City provided them with a welcoming environment that was explicitly inclusive of different religious identities, ethnicities, national backgrounds and levels of skill on the football pitch. An environment such as this, which promotes equality, is vitally important; the more inclusive the team is, the greater the participants' enjoyment of the sport. ${ }^{66}$

\section{What prevents young female Muslims from participating in football?}

Despite limited opportunities, many of the Diverse City players were already playing other team sports. However, our data shows that many of our participants did not have the same experience when it came to playing football. Many demonstrated a real investment in the game and a strong desire to play on a team, yet they had not been afforded such an opportunity outside of their schools due to a lack of clubs catering to young women and girls, Muslim and nonMuslim, alike.

I mean I could kick around a ball but I wanted to get better [but]...around where I live there is only really like boys teams so there never was really any girls teams or if there was it would end up disappearing after the year. (Sophie)

\footnotetext{
${ }^{58}$ See TSN Original, "Radical Play Part II - Ireland, March 29," accessed December 1, 2020, TSN ORIGINAL - RADICAL PLAY PART II - IRELAND on Vimeo.

${ }^{59}$ Sports Against Racism Ireland, "Hijabs and Hat-tricks."

${ }^{60}$ Ibid. See also Byrne, Louise, “Diverse City FC.” RTE News, accessed December 7, 2020, http://www.youtube.com/watch?v=HkUsH0Jcx1A.

${ }^{61}$ Sports Against Racism Ireland, "Diverse City FC Soccernites," accessed December 8, 2020, https://www.sari.ie/diverse-city-fc-soccernites/.

${ }^{62}$ Steven Bradbury, "From racial exclusions to new inclusions: Black and minority ethnic participation in football clubs in the East Midlands of England," Sociology of Sport 46, no. 1 (2010): 23-44.

${ }^{63}$ Sheila Scraton, Jayne Caudwell, and Samantha Holland, "Bend it Like Patel," International Review for the Sociology of Sport 40, no. 1 (2005): 71-88.

${ }^{64}$ Aisha Ahmad, "British football: where are the Muslim female footballers? Exploring the connections between gender, ethnicity and Islam," Soccer and Society 12, no. 3: 443-56.

${ }^{65}$ Ratna, "'Taking the power back!' The politics of British-Asian female football players."

${ }^{66}$ Mike Collins and Tess Kay, Sport and Social Exclusion, $2^{\text {nd }}$ Ed. (London and New York: Routledge, 2014).
} 
I was seventeen, eighteen, obviously I can't play with the boys anymore, so I stopped. (Rabia)

Our participants told us of facing many barriers - including interpersonal racism, both on and off the pitch - which impeded their participation in football. Two incidents in particular illustrate the racist exclusions experienced by these women within their football environments. In the following excerpt, Denise, a young, Black, Irish woman, states that she was subjected to racist abuse from her own teammates:

I played for [name of team removed] ... and we had a match and one of the girls kept saying, like, racist stuff to me like... [a girl] on me own team like, and I was...only new so I couldn't really say anything, I had no friends. They were all like, a formed group... And kept on saying stuff and I kept saying to the manager like 'Are you not going to say anything?'... and like, the referee had to stop for a player off my team giving me racist comments. (Denise)

Experiences such as these can result in diminished self-esteem and confidence for those on the receiving end. ${ }^{67}$ Despite appealing to her coach to act, nothing seemed to happen. Determined to continue to play football, Denise left her old team and eventually joined Diverse City:

I didn't go back and play and I wouldn't just go and join any team now. Like it's hard to find a team...the first thing I think of now is 'Oh am I actually going to go and are they going to accept me?'

Similarly, Deepa perceived that one of her former coaches was determined to exclude anyone who did not conform to their very narrow (and arguably racialised) understanding of what Irishness entailed. For her it was crystal clear that the basis of her exclusion from the team was her religion:

I wanted to join a football team... and see what it felt like, but I wasn't allowed to join because I am a Muslim and the team, like, the whole team was Christian, and then when I got told that I wasn't allowed to play because I am Muslim even though they knew I was a good player they were like no you are a Muslim we can't have you on the team.... He was just like no foreign people but I was like I am Muslim but he said like we just can't have you on the team so I just ended it there... but then when I got into Diverse City I went back to the team I went back to the coach and I was like this is my team, this is our team, see what we can do without you [laughs]. (Deepa)

Interestingly, non-Muslim participants reported also having had to deal with 'traditional racisms' that targeted them because of 'markers of otherness' prior to joining the club. Accordingly, we argue that teams such as Diverse City act as more than mere football clubs, demonstrating that those from minority communities do not simply accept their exclusions, with some actively resisting or negotiating ways around any barriers that stand in their way (see Ratna ${ }^{68}$ and Scratton et al. ${ }^{69}$ ).

$\mathrm{Ahmad}^{70}$ notes that Muslim women can also face 'subtle inequalities and discrimination' from within their own communities, and our data underpins Walseth's argument that older generations are often the 'driving forces behind the processes of cultural maintenance', which can result in restricting women's participation in sports. ${ }^{71}$ Our participants discussed such issues in the context of their experiences, informing us that the team had lost 'five or six players', in some cases due to parents' cultural sensitivities and generational

\footnotetext{
${ }^{67}$ Ahmad, "British football: where are the Muslim female footballers? Exploring the connections between gender, ethnicity and Islam."

${ }^{68}$ Ratna, "'Taking the power back!' The politics of British-Asian female football players."

${ }^{69}$ Scraton et al., "Bend it Like Patel."

${ }^{70}$ Ahmad, "British football: where are the Muslim female footballers? Exploring the connections between gender, ethnicity and Islam," 453.

${ }^{71}$ Walseth, "Young Muslim women and Sport: The impact of identity work," 86.
} 
perspectives on women taking part in sports. For example, Ratna has shown that acting outside of the norms of traditional cultural roles within British Asian communities is seen by some as dishonouring the family. ${ }^{72}$ Participation in sports is thus often policed by members of the wider community to ensure that community members act in accordance with preferred community norms. Awareness of being monitored subsequently polices the behaviours of all those who are being observed, affecting not just those participating in the sporting activity, but their parents too. ${ }^{73}$ Several of our participants highlighted the detrimental impact of such community policing, even when parents are comfortable with their daughters playing football.

Yeah and there's the community so I think... even if parents are comfortable with you know what, football is good, I think we're okay with them having a few bruises but what's the community going to think of it? I think that is an issue because, I haven't spoken to people but you'd hear small things and you know this girl wants to join but isn't going to join because you know her mum or her parents are worried about whatever is going to be said, you know. So there is a bit of that. There is pressure in communities... ethnic communities, religious communities, any type of ethnic community, I've seen this with people, especially older generation parents where it's a big deal to, kind of, please their surroundings, whereas with me I would hope I would follow this through with my kids that I don't really care, as long as we're living by a certain code which doesn't hurt other people, you know, if the community don't like it then that's bad for them, not bad for me. (Summayah)

Culturally because my Mum is Irish, she's not Muslim... My dad is the Muslim but yet my family still fit into the trends the girls are talking about, so my Mum would have been the one to always tell em, you know, don't do something stupid in case somebody sees you and there'd be gossip going around because you're a Muslim girl and people are going to be talking about you or whatever .... she's also the type of person that would say to me, you know, about the, um, - let's say football so 'Oh maybe you should think of giving it up because...' If I come home with like a bruise or something, you know and you're hurting yourself and you're a woman, she'd say to me 'You're a woman!!' (Ghazia).

\section{Challenging stereotypical understandings through participation in football}

It is important to clarify that a diverse range of beliefs, values and ideologies exist in our societies. Walseth sensitises us to understanding that being the epitome of a 'good woman' visà-vis involvement in sports is contingent on where one is from and how gender roles are understood within particular cultural groups in that time and place. ${ }^{74}$ It is also crucial to note that restrictive perspectives on the role of women in society are not the sole property of 'minority communities' in spite of what stereotypes employed for the purposes of othering often seem to 'show'. ${ }^{75}$ In many Western nations football is still understood as being a 'masculine activity', and female players are often treated very poorly even when they are representing their country in international competition. ${ }^{76}$ In a 2017 example of this phenomenon, members of the Republic of Ireland women's team were compelled to threaten a boycott of their international fixture against Slovakia as a consequence of their frustration at

\footnotetext{
72 Aarti Ratna, “'Who wants to make aloo gobi when you can bend it like Beckham?' British Asian females and their racialised experiences of gender and identity in women's football," Soccer and Society 12, no. 3 (2011): 382-401.

${ }^{73}$ Walseth, "Young Muslim women and Sport: The impact of identity work," 75-94.

${ }^{74}$ Ibid.

${ }^{75}$ Kumar, Islamophobia and the Politics of Empire.

${ }^{76}$ Walseth, "Young Muslim women and Sport: The impact of identity work," 86.
} 
the Football Association of Ireland's failure to deal with issues ${ }^{77}$ they had raised with the governing body. Professional Footballers' Association of Ireland (PFAI) solicitor Stuart Gilhooly said at the time that 'we need to recognise that the women's team are fifth class citizens, the dirt on the FAI's shoes' ${ }^{78}$

Ratna has also warned against 'false universalisms' when understanding the role of religion and culture and their impacts on female participation in sport. ${ }^{79}$ Different interpretations of Islam, for example, offer different perspectives on the role of women and sport (see Walseth and Fasting ${ }^{80}$ ), with some being contrary to popular belief. Ahmad (2011) determines that being seen as religiously conservative should not be understood as reflecting tendencies to limit women's participation in sport, instead emphasising the importance of personal interpretation in Islam when it comes to such issues. ${ }^{81}$ In Islam, sources such as the Qur'an, the Sunnah and the Ahadith ${ }^{82}$ are central to an individual's personal interpretation of their (and others) faith. Some use these sources to justify segregation along gender lines, while others choose to emphasise how Islam supports the participation of women in sporting activities (see Walseth and Fasting ${ }^{83}$ for a discussion of this point).

Our data suggests that our participants continuously engage in strategies of negotiation to achieve their goal: to play football. Participants stressed that they do not see their religion as being a barrier to their continued participation in football. The Muslim players from Diverse City referred to drawing on both their faith and Islamic teachings to demonstrate that female participation in sport is not only appropriate, it promotes and maintains good health and wellbeing, both of which are encouraged in Islam (see Walseth ${ }^{84}$ and Walseth and Fasting ${ }^{85}$ ).

With my mam yeah, always. I always contradict everything she says using, like, verses from the Quran like oh God didn't permit this to be forbidden or something like this, you know. (Mehreen)

You're meant to do sports...like the Prophet used to take his wife and they'd be going running around and jogging and stuff like that. Its fine, like our religion doesn't stop us from doing anything but it's just the people, the community, what they say and all. (Saddiqa)

The participants' use of Islamic sources to argue their case for participation in football highlights the agency of these Muslim women, a fact which is often denied in racialised discourses. Moreover, it demonstrates the significance of being able to draw on their

\footnotetext{
77 These issues included payments for loss of earnings and squad members having to change in and out of FAI tracksuits before and after trips away because they were not allowed to keep kit as 'players were told... that the tracksuits were needed for use by underage teams' (Malone 2017). See also Kieran Theivam (Tayvam) on Twitter: "Issues Ireland Women's National Team is looking to be resolved with FAI. Picture courtesy of @ mariecrowe. https://t.co/7XbDLZ8THU" / Twitter.

${ }^{78}$ Emmet Malone, "Ireland women's team change in toilets and share tracksuits: Players from the senior international team have voiced their grievances at the FAI," The Irish Times, April 4, 2017.

${ }^{79}$ Ratna, "'Who wants to make aloo gobi when you can bend it like Beckham?' British Asian females and their racialised experiences of gender and identity in women's football," 384.

${ }^{80}$ Kristin Walseth and Kari Fasting, "Islam's view on physical activity and sport," International Review for the Sociology of Sport 38, no. 1 (2003): 45-60.

${ }^{81}$ Ahmad, "British football: where are the Muslim female footballers? Exploring the connections between gender, ethnicity and Islam," 443-56.

${ }^{82}$ The Qur'an is the central religious text in Islam. Muslims believe it to be the word of God as revealed to the Prophet Muhammed. The Sunnah refers to how the Prophet Muhammed lived his life, and Ahadith are things that the Prophet did, said, taught or approved of, which are shared by those who were close to the Prophet. For a longer discussion see Chris Hewer, Understanding Islam: The first ten steps (London: SCM Press, 2006).

${ }^{83}$ Walseth and Fasting, "Islam's view on physical activity and sport," 45-60.

${ }^{84}$ Walseth, "Young Muslim women and Sport: The impact of identity work," 75-94.

${ }^{85}$ Walseth and Fasting, "Islam's view on physical activity and sport," 45-60.
} 
knowledge of Islam (valued own cultural capital) to legitimise their position (see also $\mathrm{Ahmad}^{86}$ ).

Stereotypical representations of Muslim men utilise the image of a tyrannical figure who is intent on restricting the life chances of his female co-religionists. ${ }^{87}$ However, our findings challenge narrow-minded and racialised understandings of Muslim fathers, who are uniformly and reductively constructed as 'hyper-patriarchal' and loath to (amongst a myriad of other things) 'allow' their daughters, wives and sisters to engage in sporting activity. ${ }^{88}$ The participants clearly contradict these racialised constructions of Muslim men through evidencing the support they have received from their fathers for their engagement with their football team.

I feel - my parents actually feel really proud that I - because I come from a background where ... girls can't play sports or girls can't go out and say kick a ball around but when my dad heard about the way this project had started ...[he] was really proud so he really wanted me to play. (Amaal)

The majority of our participants shared similar experiences with us. Indeed, echoing Walseth, one of the respondents recalled how her non-Muslim mother was more reluctant to allow her to play football than her Muslim father. ${ }^{89}$

My Dad is really supportive... if I didn't go to a training session, he'd be like 'Amina, why aren't you going training? Do you go to football anymore?' and I'd be like 'Yeah dad I do, but like it's just not on today' ... but my Mam [would say] ... 'You're a girl, you shouldn't be playing, you're Muslim!' Muslim, like, mothers would think like that. They just want, like, the daughter to be, like, like, grown up to be like a lady, kind of you know, get married and be able to cook and all this... (Laughter) ... My dad is really different. (Amina)

There was a strong sense among the participants that as a consequence of their participation in football, they potentially serve as an example to their communities and other parents, of the benefits of playing football, in turn increasing rates of participation and sowing the seeds of change for future generations to reap.

I think for me it's always been that little bit easier because both parents are very different so my mom would have the Irish stance on something but um, as a Muslim in general I think it is a big deal and I think by us playing, other parents, especially those who are not happy letting their daughters play, let's say, might change their mind over time because they'd see actually, they'd engage with us and say oh you know what, I know so-and-so and she's a really good girl and you know she's playing and she's getting loads out of it, sure what's the harm, maybe we should let our kid play or whatever, so I think it is a big change in the right direction. (Summayah)

We're the first generation, like our parents all came back from Africa, Asia, so we're the first ones growing up here. I don't think we're gonna be like that with our kids like if my daughter tells me she's gonna play football, like, I'm gonna be her trainer and all that. (Rabia)

While the participants clearly understood the structural and interpersonal barriers which impact on them, and how they can be overcome, they were also acutely aware that they are challenging hegemonic understandings of Muslim women, developing cultural and religious awareness amongst other communities and providing positive representations of female Muslims in Irish society through their participation in football with Diverse City FC.

\footnotetext{
${ }^{86}$ Ahmad, "British football: where are the Muslim female footballers? Exploring the connections between gender, ethnicity and Islam," 443-56.

${ }^{87}$ Sherene H. Razack, Casting Out: The eviction of Muslims from western law and politics (Toronto, Buffalo \& London: University of Toronto Press, 2008).

88 Ibid.

${ }^{89}$ Walseth, "Young Muslim women and Sport: The impact of identity work," 75-94.
} 
Yeah like when I played for my school I don't wear my scarf ... when I joined Diverse City I started wearing my scarf and all my teammates were like oh yeah I forgot you were a Muslim but they have a greater respect for me and I am much prouder to wear my scarf playing for my school team now as well as playing with Diverse City like it has helped me build more selfconfidence in wearing my scarf. (Amaal)

I think the fact that it was on [national] $\mathrm{TV}^{90}$ and people were like whoa! There are Muslims playing football! And sort of like, that brings up that Muslim girls aren't oppressed...that they can go out and do stuff. (Sherene)

She [School teacher] wasn't familiar with Islam and she wasn't familiar with the roles of women in Islam so I explained it to her and now she has a brief understanding that Muslim women aren't oppressed and that they can play football or sports and they are allowed to go out and so on. (Deepa)

My whole school is proud because ah I would normally talk about Diverse City and my principal, I have like a principal and she is actually doing a project about Islam and like girls and Hijabs and then when I told her about the project that we are doing she was really impressed and she wanted to find out more and we told her and like she told the whole school about it. (Amaal)

Albeit in different ways, the following participant contributions demonstrate the integrative success of the Hijabs and Hat-tricks project and Diverse City FC in particular. Deepa and Fatima both stressed the manner in which they had been brought closer together as a result of their participation.

I knew most of these before football I was already friends with them but it just kind of got us closer but there's only like a minor group of people that I did not know and we talk to each other because of football except for her she supports Liverpool [laughs]. (Fatima)

Yeah we have actually become really close like family. (Deepa)

At a broader societal level, Mehreen and Fatima demonstrate how, through their participation in the Hijabs and Hat-tricks project, they have been provided with a platform through which they can engage in activism outside of football and their own social milieus. They can share knowledge with other minority groups or engage with youth centres to develop their own understanding of the issues at hand. These activities again underscore the power of the Hijabs and Hat-tricks project as a means to enhance integration into wider Irish society.

We are sort of all like activist footballers like we don't just play football we want to tackle problems in the community - like to bring in the community more and make other minority groups involved ... So bringing in other groups and show that we are getting involved in the community and stuff and that our team wants to make a difference. (Mehreen)

I would be doing things anyways because I am part of the student council in my school so I am already active and I am involved with restorative practice in my school... That is what my school does... but it was through [SARI] that I got to know people like [name of politician removed] and then through her I got like a great placement in the Bluebell youth centre and then I joined like loads of other campaigns and I got to see like what they get to do as youth workers and they were showing me around their offices and everything.... (Fatima)

\section{Conclusions}

Action 73 of the Irish Migrant Integration Strategy states that the potential of sport in assisting migrant communities to integrate into Irish society will be 'further explored'. ${ }^{91}$ Irish policy

\footnotetext{
90 The Irish national broadcaster RTE broadcast a special feature on Diverse City.

${ }^{91}$ Department of Justice \& Equality: Office for the Promotion of Migrant Integration, The Migrant Integration Strategy: A Blueprint for the Future, 34.
} 
defines integration as the 'ability to participate to the extent that a person needs and wishes in all of the major components of society without having to relinquish his or her own cultural identity'. ${ }^{92}$ Furthermore, EU Member States agreed that integration occurs concurrently on numerous levels, in all aspects of life, with repeated contact between migrant communities and the 'native' population, and intercultural conversations about migrant communities and their cultures being amongst a number of interventions which serve to enhance the integration process. ${ }^{93}$ Against that backdrop, sport performs two essential roles; inclusion / integration in sports and inclusion / integration through sport. ${ }^{94}$ It is clear from our research that this is exactly what is happening via initiatives such as Diverse City and the Hijabs and Hat-tricks project.

The young women are challenging the existent negative stereotypes of the role of women in sport generally and in football in particular, while also providing platforms through which challenges to patriarchal structures in broader societal relations can also be launched. More specifically, the participation and indeed leadership of Irish Muslim men and women involved in the Hijabs and Hat-tricks project and Diverse City FC has had an important role, at least in their local context, in addressing the exclusions of Muslim communities and also those who are subjected to broader forms of racisms. These projects are a mechanism through which Muslim women can and do challenge racialised constructions that present them as passive victims, lacking in intellect and agency. ${ }^{95}$ Furthermore, Diverse City has provided Muslim fathers of the women involved, and male youth leaders such as Abdulkadir and Abdul-Rahman, albeit indirectly, with a means through which they challenge racialised representations that present all Muslim men as 'hyper-patriarchal'. ${ }^{96}$

For all of the men and women involved, the Hijabs and Hat-tricks initiative sends a positive image of Muslim youth as nuanced, multifaceted, rich in their diversity and engaged in their society in a hugely positive sense. This social participation goes far beyond the stock image representations of Muslim women on governmental 'integration strategies' that reduce Muslim youth to a suspect community prone to becoming 'radicalised'. Indeed, as the quotes presented previously demonstrate, the Muslim youth involved in this study are actively involved in meaningful integration on the ground, 'sort of like activist footballers'. Thus, we argue that Diverse City and similar projects should be more widely supported and developed, brought out of their local contexts and shared as good practice (inter)nationally. This would allow for the inclusion of more players and potentially further opportunities to deepen integration. In a context wherein Muslim women are disproportionately the target of antiMuslim racism in Ireland and abroad, the findings presented in this piece are of significant importance and can inform strategies for integration and inclusion in / through sport and ultimately in wider Irish society. In this regard, we leave the final word to our participants:

Sometimes you just need a lift to help you get off the floor and get started... I think that is what [Diverse City] did for us.... (Sherene)

\footnotetext{
92 Department of Justice, Equality and Law Reform. Integration: A Two Way Process.

${ }^{93}$ Council of Europe, PRESS RELEASE 2618th Council Meeting: Justice and Home Affairs, 15-18.

${ }^{94}$ Mike Collins and Rein Haudenhuyse, "Social Exclusion and Austerity Policies in England: The Role of Sports in a New Area of Social Polarisation and Inequality?" 6.

${ }^{95}$ Carr, Experiences of Islamophobia: Living with racism in the neoliberal era.

${ }^{96}$ Razack, Casting Out: The eviction of Muslims from western law and politics.
} 


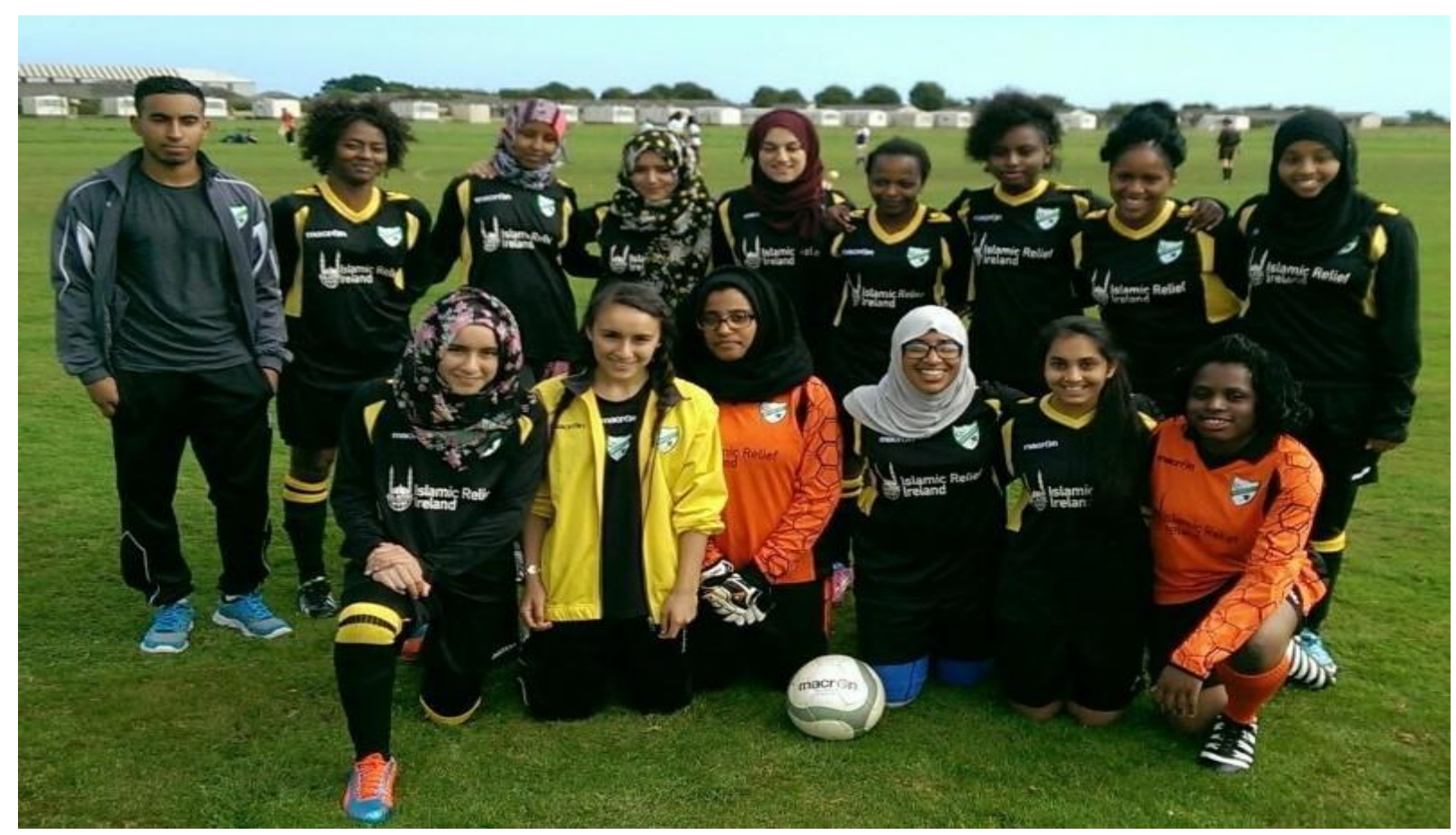

Image reproduced by kind permission of SARI.

\section{References}

Ahmad, Aisha. "British football: where are the Muslim female footballers? Exploring the connections between gender, ethnicity and Islam." Soccer and Society 12, no. 3: 44356.

Allen, Chris. Islamophobia. London: Routledge, 2010.

Blumer, Herbert. "Race Prejudice as a Sense of Group Position." The Pacific Sociological Review 1, no. 1 (Spring 1958).

Bourdieu, Pierre. "The Forms of Capital." In the Handbook of Theory and Research for the Sociology of Education, edited by John G. Richardson, 241-58. New York: Greenwood Press, 1986.

Bradbury, Steven. "From racial exclusions to new inclusions: Black and minority ethnic participation in football clubs in the East Midlands of England." Sociology of Sport 46, no. 1 (2010): 23-44.

Bray, Jennifer. "Verona Murphy apologises 'wholeheartedly' for Isis migrants claim.” The Irish Times, November 18, 2019.

Byrne, Louise. "Diverse City FC.” RTE News. Accessed December 7, 2020. http://www.youtube.com/watch?v=HkUsH0Jcx1A.

Carr, James. "Ireland 2020." In the European Islamophobia Report 2020, edited by Enes Bayrakli and Farid Hafez. Accessed December 7, 2020. https://www.islamophobiaeurope.com/.

. "Ireland 2019.” In the European Islamophobia Report 2019, edited by Enes Bayrakli and Farid Hafez. Accessed December 7, 2020.

https://www.islamophobiaeurope.com/. 
"Ireland 2018." In the European Islamophobia Report 2018, edited by Enes Bayrakli and Farid Hafez. Accessed December 7, 2020.

https://www.islamophobiaeurope.com/.

. "Ireland 2017." In the European Islamophobia Report 2017, edited by Enes Bayrakli and Farid Hafez. Accessed December 7, 2020.

https://www.islamophobiaeurope.com/.

. "Ireland 2016." In the European Islamophobia Report 2016, edited by Enes Bayrakli and Farid Hafez. Accessed December 7, 2020.

https://www.islamophobiaeurope.com/.

. "Ireland 2015." In the European Islamophobia Report 2015, edited by Enes Bayrakli and Farid Hafez. Accessed December 7, 2020.

https://www.islamophobiaeurope.com/.

. Experiences of Islamophobia: Living with racism in the neoliberal era. London: Routledge, 2016.

- Islamophobia in Dublin: Experiences and how to respond. Dublin: Immigrant Council of Ireland, 2016.

Carr, James, and Amanda Haynes. "A Clash of Racialisations: The policing of 'race' and anti-Muslim racism in Ireland.” Critical Sociology 41, no. 1 (2015): 21-40.

Carr, James, Amanda Haynes, Martin Power, Jennifer Schweppe, and John Garland. More than a club; More than a game: Contribution to the evaluation of the Hijabs and Hattricks Project. Unpublished Research Report. Accessed August 10, 2019. https://www.researchgate.net/publication/274195035_More than_a_club_more than a_game_Contribution_to the evaluation_of the_Hijabs_and_Hat-tricks_project.

Carr, James, and Martin Power. "More than a Club, More than a Game: The Case of Diverse City." Managing Sport and Leisure 25, nos.1-2 (2020): 99-113.

Coalter, Fred. "Sport-for-Change: Some Thoughts from a Sceptic." Social Inclusion 3, no. 3 (2015): 19-23.

Collins, Mike, and Rein Haudenhuyse. "Social Exclusion and Austerity Policies in England: The Role of Sports in a New Area of Social Polarisation and Inequality?" Social Inclusion 3, no. 3 (2015): 5-18.

Collins, Mike, and Tess Kay. Sport and Social Exclusion, $2^{\text {nd }}$ Ed. London and New York: Routledge, 2014.

Council of Europe. PRESS RELEASE 2618th Council Meeting: Justice and Home Affairs. Accessed August 10, 2020. https://ec.europa.eu/migrantintegration/?action=media.download\&uuid=29C7FD4E-BA62-D4EA18A8C8B34E873190.

Department of Justice. The Migrant Integration Strategy. Accessed August 10, 2020. http://www.integration.ie/en/isec/pages/migrant_integration_strategy.

Department of Justice \& Equality: Office for the Promotion of Migrant Integration. The Migrant Integration Strategy: A Blueprint for the Future. Accessed August 10, 2020. http://www.justice.ie/en/JELR/Migrant_Integration_Strategy_English.pdf/Files/Migra nt_Integration_Strategy_English.pdf.

Department of Justice, Equality and Law Reform. Integration: A Two Way Process. Dublin: Department of Justice, Equality and Law Reform, 1999. 
Finneran, Aoife. "Rise of Racism. Irish Muslim tells how racists told her to 'go back to where you came from' - despite being born in Dublin's Coolock." The Irish Sun, March 20, 2020.

Flick, Uwe. An Introduction to Qualitative Research, $3^{\text {rd }}$ Ed. London: Sage, 2006.

Football Association of Ireland. Take Part / Programmes. Accessed January 19, 2019. .https://www.fai.ie/domestic/take-part-programmes/intercultural-programme.

Football Association of Ireland. Intercultural Football Plan Many Voices One Goal, Dublin: FAI, 2007. Accessed January 19, 2019. https://www.fai.ie/sites/default/files/atoms/files/FAI_INTERCULTURAL_PLAN\%20 v1.pdf.

Gallagher, Conor. "Election 2020: Far-right candidates put in dismal showing." The Irish Times, February 10, 2020.

Haynes, Amanda, Martin Power, and Eoin Devereux. How Irish Politicians Construct Transnational EU Migrants. Limerick: Doras Luimní, 2010.

Hewer, Chris. Understanding Islam: The first ten steps. London: SCM Press, 2006.

Hillyard, Paddy. Suspect community: people's experience of the Prevention of Terrorism Acts in Britain. London: Pluto Press, 1993.

Hoodfar, Homa. "The Veil in Their Minds and on Our Heads: The persistence of colonial images of Muslim women." Resources for Feminist Research 22, no. $3 / 4$ (1993): 518.

Hussein, Shakir, Scheherazade Bloul, and Scott Poynting. "Diasporas and dystopias on the beach: Burkini wars in France and Australia." In The Routledge International Handbook of Islamophobia, edited by Irene Zempi and Imran Awan, 263-75. London and New York: Routledge, 2019.

Kemper, Theodore D., and Randall Collins. "Dimensions of Microinteraction." The American Journal of Sociology 96, no. 1 (1990): 32-68.

Kumar, Deepa. Islamophobia and the Politics of Empire. Chicago: Haymarket Books, 2012.

Kuper, Simon. Football Against the Enemy. London: Phoenix, 1996.

Malone, Emmet. "Ireland women's team change in toilets and share tracksuits: Players from the senior international team have voiced their grievances at the FAI." The Irish Times, April 4, 2017.

Michael, Lucy. 2019. Data from iReport.ie: Reports of Racism in Ireland 2019. Irish Network Against Racism. https://inar.ie/wpcontent/uploads/2020/03/2019_iReport_Final.pdf.

Ní Chonaill, Bríd. Integration Through Football Project: First phase evaluation. What we know so far? Report for the Football Association of Ireland. Accessed February 21, 2019.

https://www.fai.ie/sites/default/files/atoms/files/Integration\%20Through\%20Football \%20Project\%20first\%20phase\%20Report.pdf.

Ombudsman for Children. Direct Division: Children's views and experiences of living in Direct Provision: A report by the Ombudsman for Children's Office 2020. Accessed November 10, 2020. https://www.oco.ie/app/themes/oco/images/directdivision/pdf/Ombudsman-for-Children-Direct-Division-Report-2020.pdf. 
Parnell, Daniel, and David Richardson. "Introduction: Football and inclusivity." Soccer \& Society 15, no. 6 (2014): 823-27.

Power, Martin. "Outwitting the Gatekeepers of the Purse: The Impact of Micro Level Interactions in Determining Access to the Back to Education Allowance Welfare to Education Programme." International Review of Modern Sociology 35, no. 1 (2009): $25-42$.

Power, Martin, James Carr, Daniel Parnell, Paul Widdop, and Stephen Millar. "Introduction: Understanding The Connection Between Football, Identity and (P)politics." In Football, Politics and Identities, edited by James Carr, Daniel Parnell, Paul Widdop, Martin Power, and Stephen Millar, 1. London and New York: Routledge, 2021.

Power, Martin, Amanda Haynes, and Eoin Devereux. "From the mouths of Janus: Political Constructions of Transnational EU Migrants." Irish Communications Review 13, no. 1 (2012): 3-18.

Ratna, Aarti. "'Taking the power back!' The politics of British-Asian female football players." Young 18, no. 2 (2010): 117-132.

Ratna, Aarti. “'Who wants to make aloo gobi when you can bend it like Beckham?' British Asian females and their racialised experiences of gender and identity in women's football." Soccer and Society 12, no. 3 (2011): 382-401.

Razack, Sherene H. Casting Out: The eviction of Muslims from western law and politics. Toronto, Buffalo \& London: University of Toronto Press, 2008.

Scraton, Sheila, Jayne Caudwell, and Samantha Holland. "Bend it Like Patel." International Review for the Sociology of Sport 40, no. 1 (2005): 71-88.

Spaaij, Ramón, Jonathan Magee, and Ruth Jeanes. Sport and social exclusion in global society. New York: Routledge, 2014.

Sports Against Racism Ireland. "Positive Integration and Social Inclusion Through Sport." Accessed November 20, 2020. https://www.sari.ie/.

Sports Aainst Racism Ireland. (2017a) "Hijabs and Hat-tricks.” Accessed November 11, 2020. http://www.sari.ie/hijabs-and-hat-tricks/.

Sports Against Racism Ireland. (2017b) "Diverse City FC Soccernites." Accessed December 8, 2020. https://www.sari.ie/diverse-city-fc-soccernites/.

Torres, Cesar R., and Douglas W. McLaughlin. "FIFA and the Lifting of the Ban on the Hijab." Play The Game. Accessed November 11, 2020. https://www.playthegame.org/news/news-articles/2014/fifa-and-the-lifting-of-theban-on-the-hijab/.

TSN Original. "Radical Play Part II - Ireland, March 29.” Accessed December 1, 2020. TSN ORIGINAL - RADICAL PLAY PART II - IRELAND on Vimeo.

Walseth, Kristin. "Young Muslim women and Sport: The impact of identity work." Leisure Studies 25, no. 1 (2006): 75-94.

Walseth, Kristin, and Kari Fasting. "Islam's view on physical activity and sport." International Review for the Sociology of Sport 38, no. 1 (2003): 45-60. 